\title{
Response of Soybean Genotypes to Different Levels of Mutagens for Yield Related Attributes
}

\author{
Sajid Hussain*, Zahid Akram, Ghulam Shabbir and Qadeer Ahmad \\ Department of Plant Breeding and Genetics, Pakistan
}

*Corresponding author: Sajid Hussain, Department of Plant Breeding and Genetics, PMAS Arid Agriculture University, Pakistan

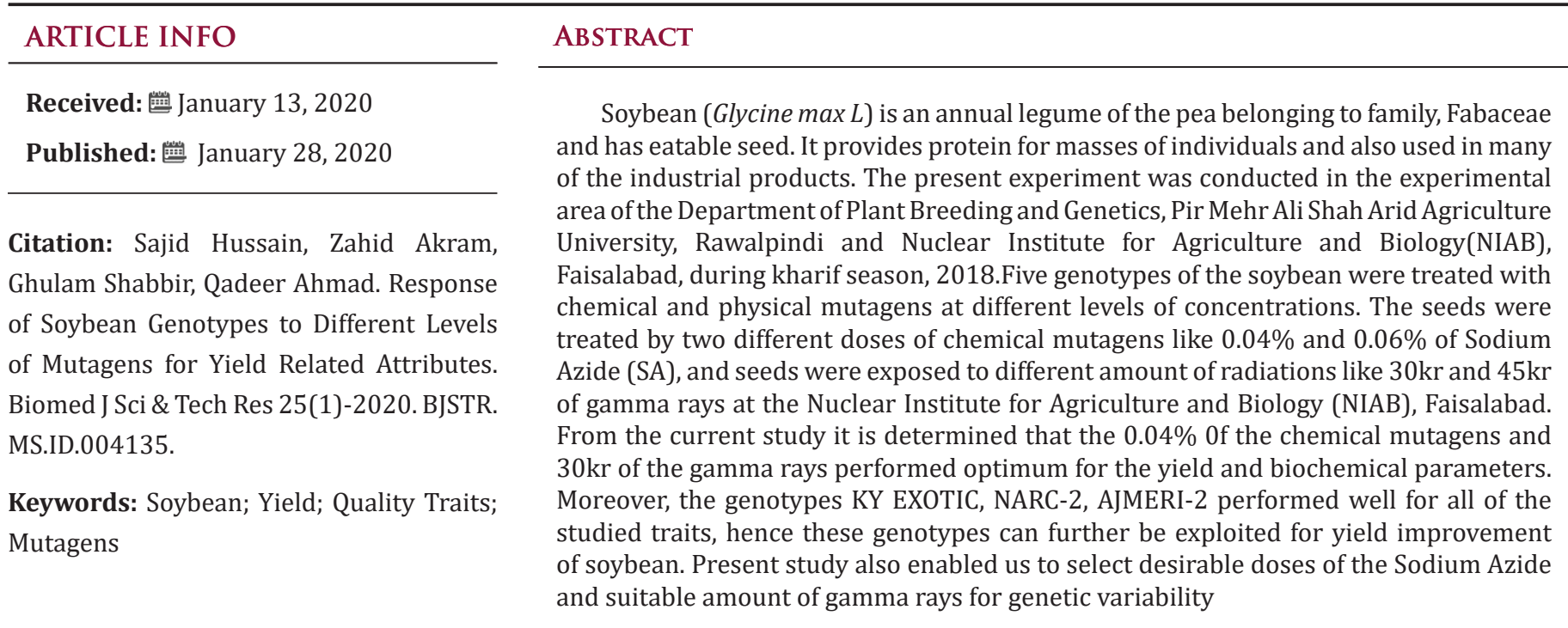

\section{Introduction}

Soybean (Glycine max L.) has a significant nutritional value. It comprises around $40 \%$ protein and $20 \%$ oil content. Soybean protein has valuable amino acid lysine (5\%). Additionally, it also includes a good number of vitamins like thiamine and riboflavin, salts and minerals [1] Pakistan is fronting a severe scarcity of edible oils. The native edible oil production does not complete the increasing needs of population. The entire accessibility of eatable oils in 2015-16 remained at 3.726 million tons. Home-grown production mounted at 0.85 million tons which accounts for $28 \%$ of whole accessibility. The lasting $72 \%$ was completed by import [2]. Edible oil is the major diet element being trade in in the country. The importation bill of eatable oil was about Rs.18.43 billion in 2001-02 and has increased up to Rs. 109.13 billion in 2007-08 and the importation bill was 2.710 billion \$ in 2015-16 [2]. Mutation breeding is an operative means in crop plants, particularly in crops having narrow genetic base, in hands of plant breeders. Numerous mutants have been recognized as contributors of required characters in breeding program. Mutation refinement effort in recognition of several mutant lines with required characters like high growth and existence \%, has generated in soybean. Dissimilarities in M1 generation, though less significant in opinion of gaining stable gene mutations, are often measured as indicators in calculating effectiveness of mutagen treatments [3]. Radioactivity is a vital ecological strain which disturbs all breathing creatures. Ionizing radioactivity distresses cellular mechanisms; thus, possibly persuading functional variations in plants. Assessment of these biotic variations is very vital as they arise through such physicochemical variations. Ionization, detachment and excitation are the principal possessions of ionizing energy and outcome after energy deposition in the treated substantial. Ionizing energy. produces $\cdot \mathrm{OH}$ and $\mathrm{O}_{2} \cdot$ and induces injury in cellular casings [4].

\section{Objectives}

Following are the objectives of the present experiment.

a) Induction of the chemical and physical mutagens.

b) Study of effects on morphological traits of the soybean. 


\section{Material and Method}

\section{Preparation of Sodium Azide}

Solution of sodium azide was prepared in the laboratory, Department of Plant Breeding and Genetics, NIAB, Faisalabad. 0.04 grams of sodium azide were added in $100 \mathrm{ml} \mathrm{H}_{2} \mathrm{O}$ to prepare $0.04 \%$ and 0.06 grams of SA were added in $100 \mathrm{ml}$ of water to prepare $0.06 \%$ of SA.

\section{Mutagenesis}

In the first experiment the seeds of five Soybean genotypes, (PGRI-15, KY EXOTIC, NARC-, AJMERI-2, AJMERI) was subjected to mutation. The seed was treated at Nuclear Institute for Agriculture and Biology (NIAB), Faisalabad, with two different mutagenesis, Physical and Chemical mutagenesis. In physical mutation the seed was exposed to the gamma rays, $30 \mathrm{KR}$ and $45 \mathrm{KR}$. In chemical mutagenesis the seed of equal size was subjected to $0.04 \%$ and $0.06 \%$, SA. For each of the chemical treatment the seed was presoaked in the distilled water. After soaking with the distilled water, the seed was dried and treated with different concentrations $(0.04 \% \& 0.06 \%)$ of the chemical for 6 hours tracked by washing of seeds by tape water for 2 hours. Second experiment was conducted at the Glass house, at the research site of the, Department of Plant Breeding \& Genetics, PirMehr Ali Shah Arid Agriculture University, Rawalpindi, following Randomized Block Design (RCBD). The seeds treated with the Chemical, Physical and untreated (control) were sown in the pots with two replications.

\section{Morphological Traits}

Data were recorded on the following morphological traits.

Germination Percentage: The emergence of the seed was recorded as germination percent. After sowing the seeds propagation percentage was intended by following method (Figure 1).

Germination \% age $=$ Total no. of germinated plants $\times 100$ Total seed sown

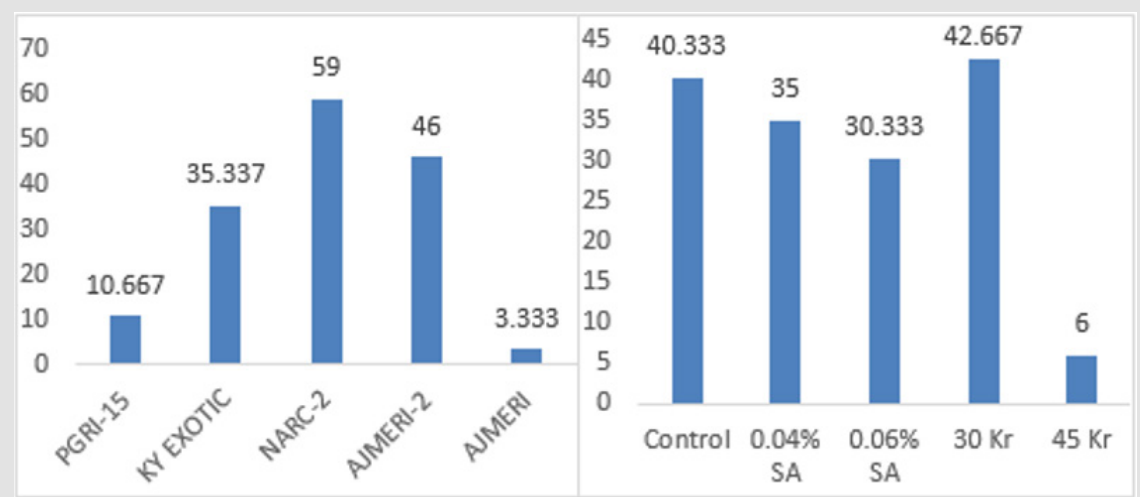

Figure 1: Germination percentage.

Plant Height (cm): Plant height at maturity was measured in $\mathrm{cm}$ from the base of plant to the top. Height was measured from five arbitrarily selected plants of each genotype in $\mathrm{cm}$ and their middling was calculated (Figure 2).

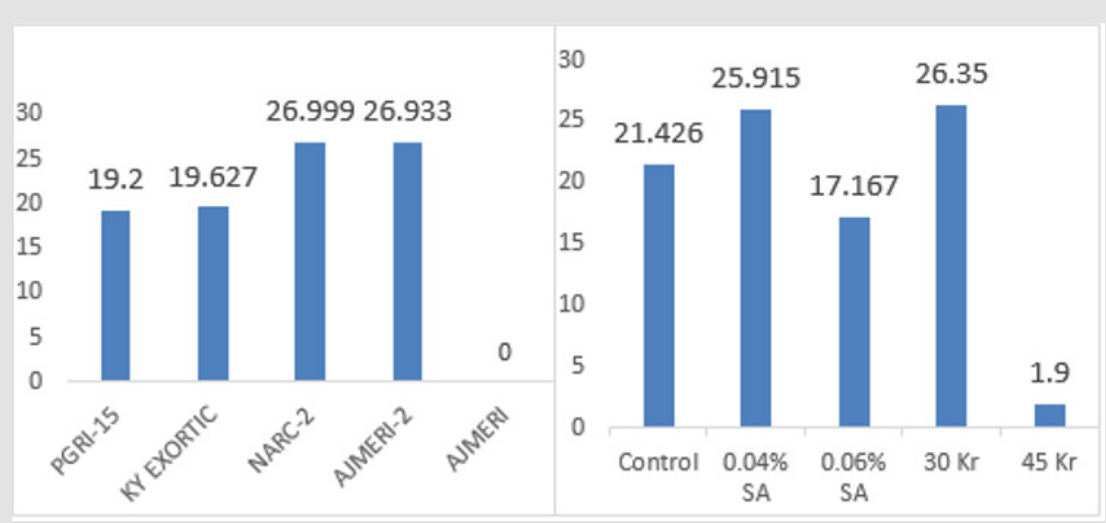

Figure 2: Plant height.

Number of Pods per Plant: Average numbers of fully formed pods/ plant from arbitrarily selected five plants were taken and numbers of pods from respectively plant were calculated.

\section{Number of Seeds per Pod}

Number of seeds per pod was determined by calculating the seeds from irregularly particular pods from respectively genotype and their middling was calculated (Figure 3). 


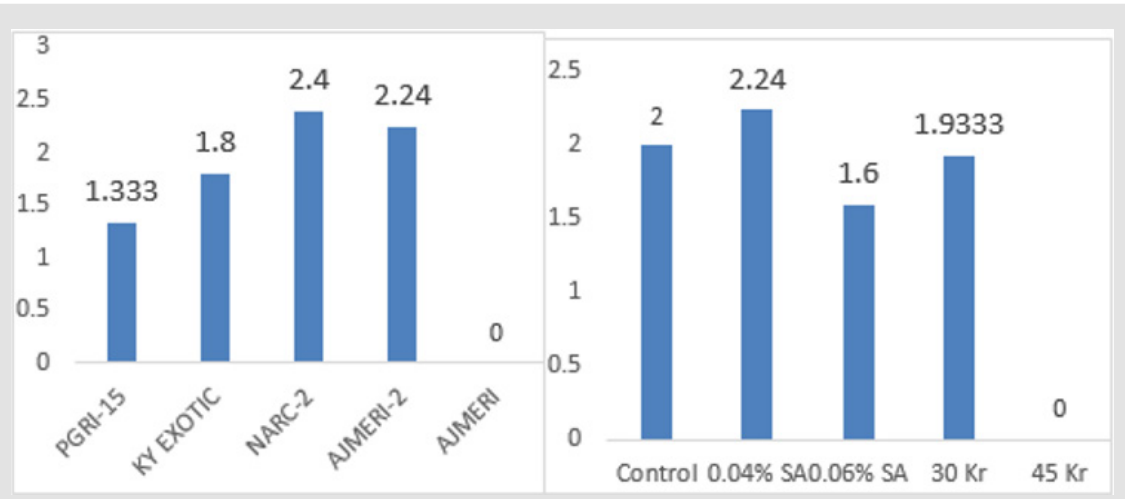

Figure 3: Seed/pod.

Days to First Flowering: Days to first flowers were taken visually by counting the time from the day of sowing to the date once plants bloomed their first flower in each genotype (Figure 4\&5).
Hundred Grain Weight (g): 100-grains were taken at random from each genotype and balanced in gram by the use of electronic weight balance (Figure 6\&7).

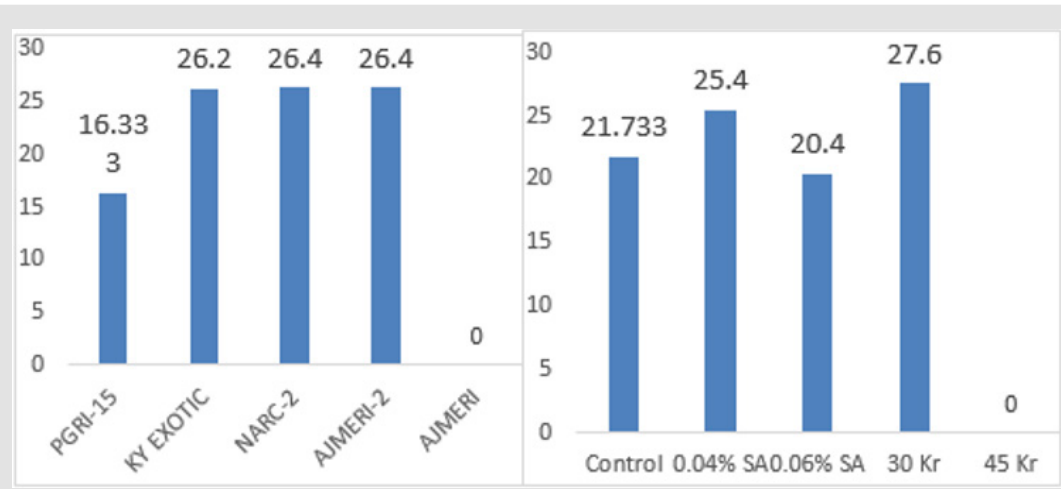

Figure 4: Days to first flowering.

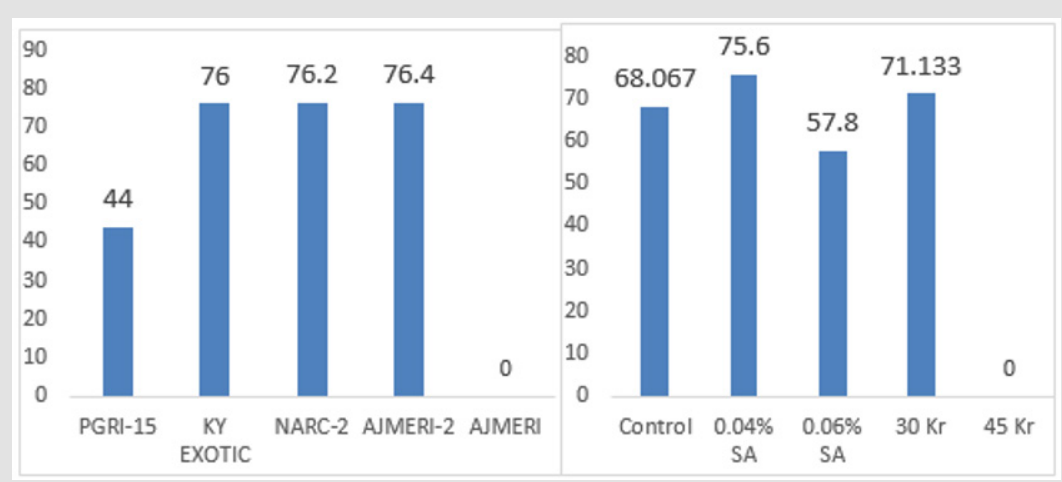

Figure 5: Days to Maturity.

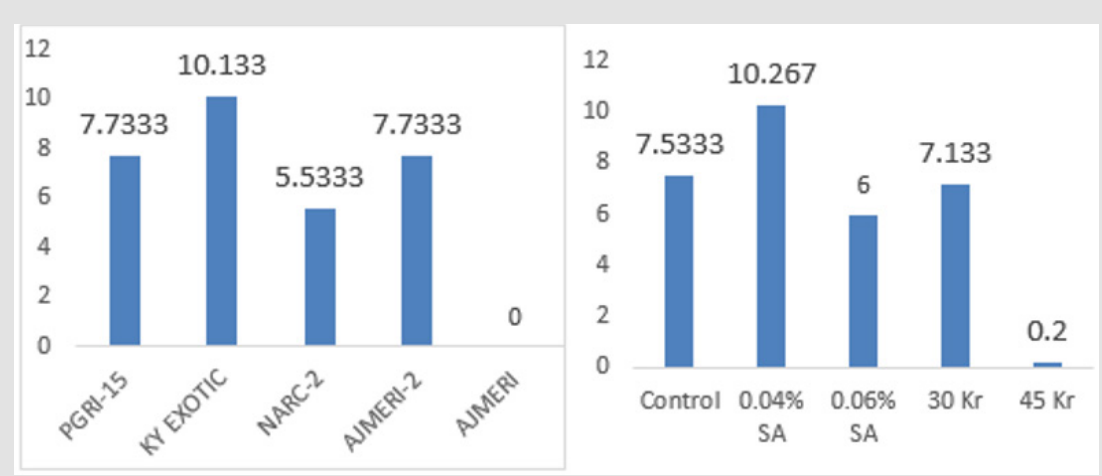

Figure 6: Pods/plant. 


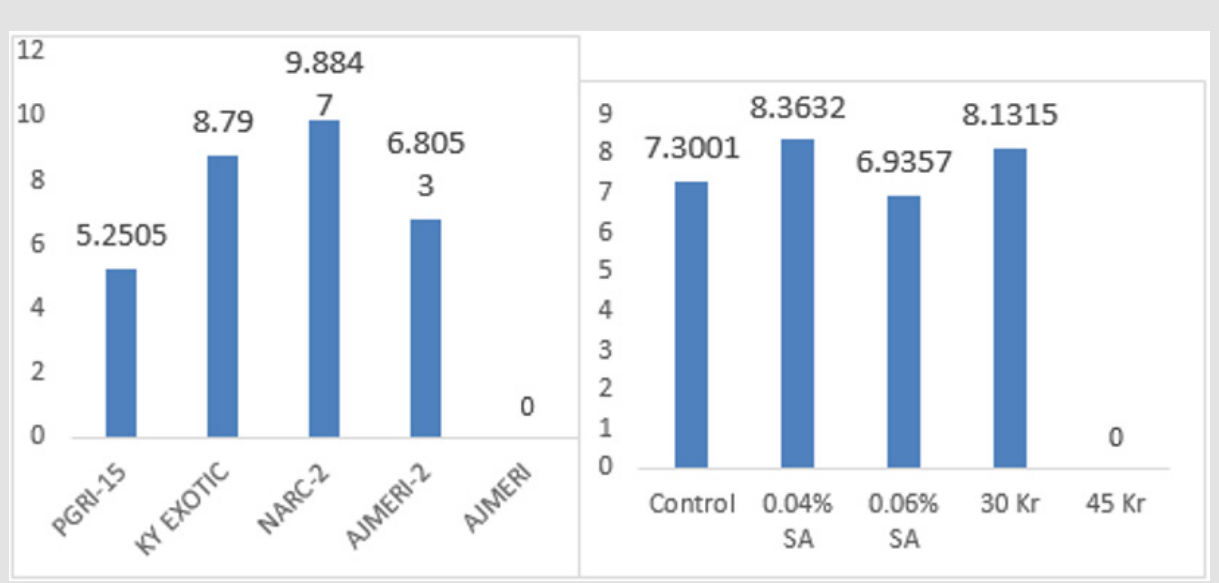

Figure 7: Hundred grain weight.

\section{Biochemical Traits}

The data for soybean biochemical traits were recorded which are described below.

Oil Content: Fat and Oil content was determined by the Soxhlet extraction method at Grain Quality Testing Laboratory, National Agriculture Research center (NARC), Islamabad. Soxhlet apparatus was used to isolate the fat and oil content. Oil percentage was determined on the basis of weight difference (Figure 9).

Protein Content: Protein content was determined by Kjeldahl method at Grain Quality Testing Laboratory, National Agriculture Research Center (NARC), Islamabad.K-jeldahl method was used to determine the nitrogen content and then converted it protein content (Figure 8).

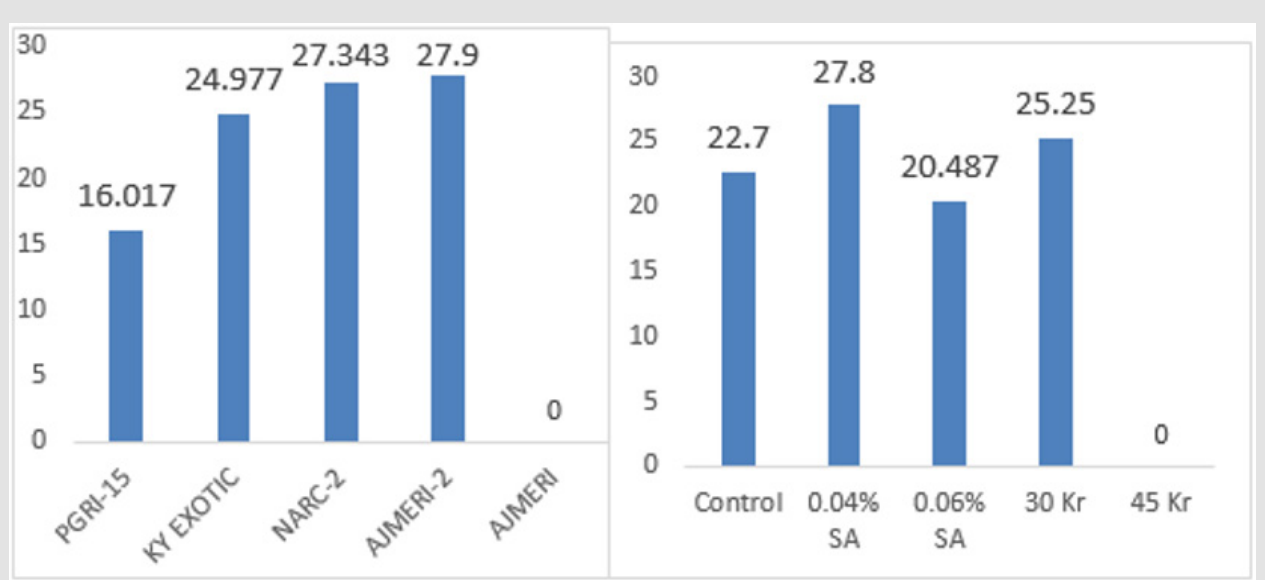

Figure 8: Protein content.

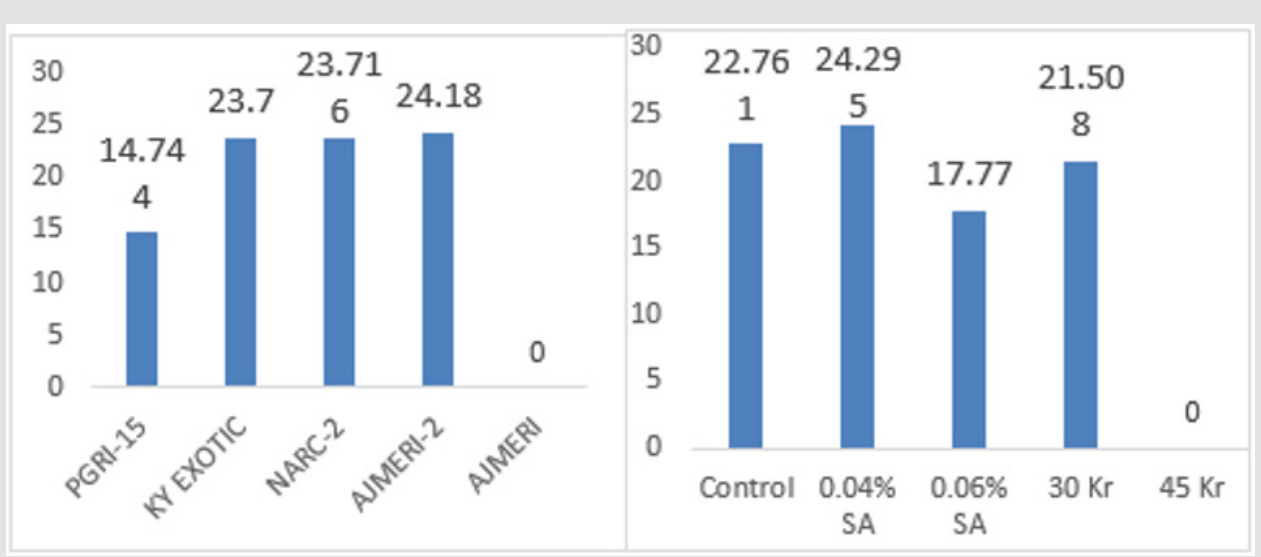

Figure 9: Oil content. 


\section{Statistical Analysis}

The data thus composed were exposed to study of variance (ANOVA) procedure Steel et al., (1997) for entirely the characters deliberate to observe the significant variances among the genotypes. Data were statistically investigated through (Statistix8.1) processor software. The difference among the treatment means was compared by the Fisher Least Significant Difference (LSD) test at 0.05 P-value and correlation coefficient, was also studied as described by [5] and determined the association between yield and yield component.

\section{Results and Discussion}

Soybean is an important oil seed crop. Pakistan is fronting the scarcity of edible oil because it is grown in a limited area. The present study was conducted for yield and quality improvement of the crop in the research site of the Department of Plant Breeding and Genetics, PirMehr Ali Shah Arid Agriculture University, Rawalpindi. The five genotypes of the soybean were treated with the Chemical mutagens viz. Sodium Azide and physical mutagens viz. gamma rays at different doses, to create genetic variation in the crop. For the current experiment the genotypic, phenotypic and environmental correlation was also determined to specify the correlation among yield related attributes. The result showed that germination percentage for the soybean genotypes, in control was $40.33 \%$ (Table 2), while germination percentage for the genotypes in which the physical mutagens applied were high as compared to control. The results showed that with the rise in concentration of the mutagens applied, itlead to the decrease in the germination percent. The findings of the existing study also commensurate [6] and [7] who also reported that the emergent percentage decreases with the increase in mutagens concentrations.

Among all the genotypes, the results (Table 2) exhibited highly significant variances for plant height. In which the genotypes NARC-2 and AJMERI-2 showed the height of $26.99 \mathrm{~cm}$ and 26.933 $\mathrm{cm}$ respectively. The results of the present study also related [8] in which they described that the plant height decreases with the rise in the concentration of the SA. The results (Table 1) discovered that all the genotypes showed exceedingly substantial differences for seeds / pod. The conclusions (Table 1) coincided that the genotypic and treatment interaction showed significant results for number of seeds/pods. Pertaining to results (Table 2), the genotypes, PGRI-15 (1.33), KY EXOTIC (1.8), NARC-2 (2.4), AJMERI-2 (2.24) and AJMERI (00) seeds per pod among the genotypes, NARC-2 and AJMERI-2 indicates significant results for the seeds per pod as 2.4 and 2.24 respectively. The results of the present study commensurate in which they reported that with [8] the increase in doses of the mutagens the number of seeds decreases. Overall the conclusions (Table 2) expressed that the genotype PGRI-15(16.333), exhibited significance differences for days to first flowering.In chemical mutagens the results showed 20.400 at dose of $0.06 \%$ of SA and the days to first flowering decreased at $0.04 \%$ of SA. These days to first flowering for physical mutagens $30 \mathrm{kr}$ was 27.

Table 1: Anova for different soybean and yield related traits.

\begin{tabular}{|c|c|c|c|c|c|c|c|c|c|c|c|}
\hline SOV & DF & GP & PP & NSP & FFG & DM & NPP & HGW & PP & OC & PC \\
\hline Genotypes & 4 & $8274.67^{* *}$ & $1827.50^{* *}$ & $13.9141^{* *}$ & $1974.55^{* *}$ & $16849.7^{* *}$ & $221.453^{* *}$ & $224.920^{* *}$ & 2111.87 & $1632.28^{* *}$ & \\
\hline Treatment & 4 & $3242.17^{* *}$ & $1509.36^{* *}$ & $112.1141^{* *}$ & $1820.05^{* *}$ & $14576.5^{* *}$ & $207.087^{* *}$ & $182.202^{* *}$ & 1899.89 & $1484.86^{* *}$ & \\
\hline $\begin{array}{c}\text { Genotypes x } \\
\text { Treatment }\end{array}$ & 16 & $548.00^{* *}$ & $266.83^{* *}$ & $1.7791^{* *}$ & $227.18^{* *}$ & $1775.7^{* *}$ & $50.103^{* *}$ & $30.394^{* *}$ & 240.21 & $177.28^{* *}$ & \\
\hline Replication & 2 & 184.33 & 9.01 & 0.3301 & 10.45 & 476.3 & 1.773 & 99.95 & 34.20 & 57.34 & \\
\hline Error & 48 & 169.06 & 36.04 & 0.2135 & 10.45 & 228.4 & 12.537 & 3.957 & 35.48 & 27.17 & \\
\hline
\end{tabular}

Note: GP: Germination percentage, $\mathrm{PH}=$ Plant height, NSP= Number of seed/pod DFF= Days to flowering, DM= Days to maturity, $\mathrm{NPP}=$ Number of pods $\mathrm{HGW}=$ Hundred grain weight, $\mathrm{PP}=$ protein percent, $\mathrm{OP}=$ Oil percentage

Table 2: Mean of different yield and quality traits of 9 characters in 5 soybean genotypes.

\begin{tabular}{|c|c|c|c|c|c|c|c|c|c|}
\hline Genotypes & GP & PH & NSP & DFF & Maturity & NPP & HGW & PP & OP \\
\hline PGRI-15 & 10.667 & 19.200 & 1.333 & 16.333 & 44.000 & 7.7333 & 5.2505 & 16.017 & 14.744 \\
\hline KY EXOTIC & 35.337 & 19.627 & 1.8000 & 26.200 & 76.000 & 10.133 & 8.7900 & 24.977 & 23.700 \\
\hline NARC-2 & 59.00 & 26.999 & 2.4000 & 26.400 & 76.200 & 5.5333 & 9.8847 & 27.343 & 23.716 \\
\hline AJMERI-2 & 46.00 & 26.933 & 2.2400 & 26.400 & 76.400 & 7.7333 & 6.8053 & 27.900 & 24.180 \\
\hline AJMERI & 3.333 & 0.0000 & 0.000 & 0.000 & 0.000 & 0.000 & 0.000 & 0.000 & 0.000 \\
\hline Mutagens & GP & PH & NSP & DFF & Maturity & NPP & HGW & PP & OP \\
\hline Control & 40.333 & 21.426 & 2.0000 & 21.733 & 68.067 & 7.5333 & 7.3001 & 22.700 & 22.761 \\
\hline $0.04 \% \mathrm{SA}$ & 35.000 & 25.915 & 2.2400 & 25.400 & 75.600 & 10.267 & 8.3632 & 27.800 & 24.295 \\
\hline $0.06 \% \mathrm{SA}$ & 30.333 & 17.167 & 1.6000 & 20.400 & 57.800 & 6.000 & 6.9357 & 20.487 & 17.77 \\
\hline $30 \mathrm{Kr}$ & 42.667 & 26.350 & 1.9333 & 27.600 & 71.133 & 7.133 & 8.1315 & 25.250 & 21.508 \\
\hline
\end{tabular}




\begin{tabular}{|c|c|c|c|c|c|c|c|c|c|}
\hline $45 \mathrm{Kr}$ & 6.000 & 1.900 & 0.000 & 0.000 & 0.000 & 0.200 & 0.000 & 0.000 & 0.000 \\
\hline Control & 40.333 & 21.426 & 2.0000 & 21.733 & 68.067 & 7.5333 & 7.3001 & 22.700 & 22.761 \\
\hline
\end{tabular}

Note: GP: Germination percentage, $\mathrm{PH}=$ Plant height, NSP= Number of seed/pod DFF= Days to flowering,, $\mathrm{NPP}=\mathrm{Number}$ of pods per plant $\mathrm{DM}=$ Days to maturity, $\mathrm{HGW}=$ Hundred grain weight, $\mathrm{PP}=$ protein percent, $\mathrm{OP}=\mathrm{Oil}$ percentage

While the results showed 21.733 for control plants. The results of the present study were also supported by [9] which they reported that days to first flowering were improved with the rise in the doses of the mutagens. The products (Table 1) coincided that the genotypes obtained highly significant variances for the days to maturity. The results (Table 1) revealed that the genotypic and treatment interaction showed significant results for days to maturity. The findings (Table 2) predicted for days to maturity the genotypes, PGRI-15 (44), KY EXOTIC (76), NARC2(76.2), AJMERI-2(76.4), AJMERI (00). Among all the genotypes, the genotype PGRI-15 (44) showed maximum significant for days to maturity. The results for days to maturity for chemical mutagens at dosage $0.04 \%$ was 75.6 and at $0.06 \%$ was 57.8 , of SA. Whereas the days to maturity for physical mutagens at $30 \mathrm{kr}$ was 71.133 and 68.067 for control. The results of the present study [7] in which they reported that the maturity period decreases with the increase in the mutagens concentrations. The outcomes (Table 1) accorded that the genotypic and treatment interaction showed significant results for number of pods/plants.

The results for number of pods/plant (Table 2) pretended for the genotypes, KY EXOTIC (10.133) showed highly significant. The pods per plant (10.267) increased at dosage of $0.04 \%$ which decreased (6) at $0.06 \%$ SA, the number of pods per plant observed (7.133) for $30 \mathrm{kr}$ of gamma rays, which decreases at high amount of the radiations. For the control it was noted 7.5333. Our results were [9] in which they reported that number of pods is high in mutant genotype as compare to the control. The findings (Table 1) revealed that all the genotypes presented significant differences for hundred grain weight. The products (Table 2) predicted that the genotypes, KY EXOTIC and NARC-2, showed highly significance for the hundred grain weight, $8.7900 \mathrm{~g}$ and $9.8847 \mathrm{~g}$ respectively. The results for the chemical mutation showed 8.3632 and 6.9357 at dosage of $0.04 \%$ and $0.06 \%$ SA respectively, while the results for physical mutation, gamma rays, the grain weight showed 8.1315 at amount of $30 \mathrm{kr}$ and 7.300 (g) grain weight for control [10] in which they reported that the grain weight increased due to induced mutation as compared with the control where mutation was not induced.

The results (Table 2) for protein content were observed highly significant for the genotypes, NARC-2, AJMERI-2, 27.343 and 27.900 respectively. The results (Table 2) coincided for Protein content showed that the genotypes on which mutagens applied, was highly significant compare with the control. The protein content for the genotype which was treated with the chemical mutagens showed high protein content 27.800 at dosage of $0.04 \%$. The results were also supported by [1] in which they reported that the protein content was different for different dosage of the mutagens. The findings (Table 2) detected for each genotypes, PGRI-15 (16.017), KY EXOTIC (24.977), NARC-2 (27.343), AJMERI-2 (27.900) and AJMERI (00) among which highly significance were perceived for the genotypes, KY EXOTIC, NARC-2, AJMERI-2, in which the fats and oil content ranged from 14- 24.180. The results showed that the fats and oil content for the control were 20.761, while the results for chemically mutant genotypes were 24.295 at dosage of $0.04 \%$ and 17.77 for $0.06 \%$ of SA and 21.508 was observed at $30 \mathrm{kr}$ of gamma rays in physical mutagens. Kavithamani et al. [1] in which they reported that the fats and oil content increases due to mutation. Different dosage of the mutagens had different effect on the fats and oil content.

\section{Correlation Analysis}

Estimation of phenotypic correlation between yield components and quality traits as well as among the components themselves is presented (Table 3). The correlation among different characters are described and discussed as under. The seeds/pod highly correlated with the days to first flowering (0.9545), days to maturity (0.9710), pods/plant (0.8343), hundred grain weight (0.9345) and quality traits like protein (0.9768) and oil content (0.9696).The findings of the present study assembled with the results of the [11] in which they conveyed that number of seeds per pod positively correlated with the yield related traits. The outcomes also observed that the genotypic, phenotypic and environmental correlation was highly significant. The number of pods per plant correlation showed highly significant results with the hundred grain weight $(0.8311)$, protein (0.8781) and oil content (0.8884).The present study is also supported by [11] in which they showed positively high correlation of pods/plant. The consequences of our study resembled with the [12] in which they revealed that the number of pods/plants definitely correlated with the plant height, Days to flowering, Days to maturity.

The hundred grain weight correlated with the protein and oil content, 0.9469 and 0.9523 respectively. The findings reported by [12] that Hundred grain weight, negatively correlated with other yield related traits. Observation of the present study showed positive correlation of the hundred grain weight, which may be because of genotypes, environmental effects or that may be because of the mutation induced. The results of the present study were supported by [11] in which they reported that hundred grain weight positively correlates with the yield related traits. The protein content showed high correlation with the oil content (0.9913). Our results collate with [9] findings that protein content 
is significant and positive correlated with oil content. The results (Table 3) showed that fat and oil contented was highly correlated with yield related traits. The results also intimated that the genotypic, phenotypic and environmental association for fats and oil content is highly significant. The outcomes of the current study resembled with the results of [1] who described that a confident correlation was found between oil content and grain yield and a negative significant correlation were found between oil content and protein content. But in the present study the effect might be due to genotypic, environmental effect or that may be because of mutation induced [13-15].

Table 3: Correlation between Different Soybean genotypes for Yield and Quality traits.

\begin{tabular}{|c|c|c|c|c|}
\hline CHAR. & $r(g)$ & $r(p)$ & $r(e)$ & $r(s)$ \\
\hline 12 & $0.8078^{* *}$ & $0.7577^{* *}$ & $0.5130^{* *}$ & $0.7890^{* *}$ \\
\hline 13 & $0.8808^{* *}$ & $0.7672^{* *}$ & $0.1380^{* *}$ & $0.8384^{* *}$ \\
\hline 14 & $0.8679 * *$ & $0.7759^{* *}$ & $0.1360^{* *}$ & $0.8338^{* *}$ \\
\hline 15 & $0.8784^{* *}$ & $0.7711^{* *}$ & $0.1621^{* *}$ & $0.8384^{* *}$ \\
\hline 16 & $0.5045^{* *}$ & $0.4436^{* *}$ & $0.2606^{* *}$ & $0.4801^{* *}$ \\
\hline 17 & $0.8301^{* *}$ & $0.7342^{* *}$ & $0.2342^{* *}$ & $0.7942^{* *}$ \\
\hline 18 & $0.8736^{* *}$ & $0.7602^{* *}$ & $0.1293^{* *}$ & $0.8313^{* *}$ \\
\hline 19 & $0.8745^{* *}$ & $0.7634^{* *}$ & $0.1699 * *$ & $0.8330^{* *}$ \\
\hline 23 & $0.9600^{* *}$ & $0.9055^{* *}$ & $0.5125^{* *}$ & $0.9402^{* *}$ \\
\hline 24 & $0.9608^{* *}$ & $0.9149^{* *}$ & $0.5318^{* *}$ & $0.9443^{* *}$ \\
\hline 25 & $0.9551^{* *}$ & $0.9025^{* *}$ & $0.5118^{* *}$ & $0.9360^{* *}$ \\
\hline 26 & $-0.8737 \mathrm{~ns}$ & $-0.7972 \mathrm{~ns}$ & $-0.5682 \mathrm{~ns}$ & $-0.8429 \mathrm{~ns}$ \\
\hline 27 & $-0.9093^{*}$ & $0.8537 \mathrm{~ns}$ & $-0.4786 \mathrm{~ns}$ & $-0.8890 \mathrm{~ns}$ \\
\hline 28 & $0.9770^{* *}$ & $0.9157^{* *}$ & $0.4720^{* *}$ & $0.9548^{* *}$ \\
\hline 29 & $0.9575^{* *}$ & $0.9039 * *$ & $0.5334^{* *}$ & $0.9380^{* *}$ \\
\hline 34 & $0.9545^{* *}$ & $0.9312^{* *}$ & $0.7300^{* *}$ & $0.9462^{* *}$ \\
\hline 35 & $0.9710^{* *}$ & $0.9695^{* *}$ & $0.9577^{* *}$ & $0.9705^{* *}$ \\
\hline 36 & $0.8343^{* *}$ & $0.7873^{* *}$ & $0.6972^{* *}$ & $0.8149^{* *}$ \\
\hline 37 & $0.9345^{* *}$ & $0.9267^{* *}$ & $0.8688^{* *}$ & $0.9317^{* *}$ \\
\hline 38 & $0.9768^{* *}$ & $0.9702^{* *}$ & $0.9148^{* *}$ & $0.9744^{* *}$ \\
\hline 39 & $0.9696^{* *}$ & $0.9673^{* *}$ & $0.9507^{* *}$ & $0.9687^{* *}$ \\
\hline 45 & $0.9958^{* *}$ & $0.9681^{* *}$ & $0.6721^{* *}$ & $0.9860^{* *}$ \\
\hline 46 & $0.8702^{* *}$ & $0.7728^{* *}$ & $0.5062^{* *}$ & $0.8312^{* *}$ \\
\hline 47 & $0.9687^{* *}$ & $0.9274^{* *}$ & $0.5526^{* *}$ & $0.9539 * *$ \\
\hline 48 & $0.9966^{* *}$ & $0.9610^{* *}$ & $0.5822^{* *}$ & $0.9840^{* *}$ \\
\hline 49 & $0.9919^{* *}$ & $0.9601^{* *}$ & $0.6896^{* *}$ & $0.9805^{* *}$ \\
\hline 56 & $0.8822^{* *}$ & $0.8190^{* *}$ & $0.6680 \mathrm{~s}$ & $0.8564^{* *}$ \\
\hline 57 & $-0.9618 \mathrm{~ns}$ & $-0.9547 \mathrm{~ns}$ & $-0.9044 \mathrm{~ns}$ & $-0.9592 \mathrm{~ns}$ \\
\hline 58 & $0.9950^{* *}$ & $0.9918^{* *}$ & $0.9646^{* *}$ & 0.9939** \\
\hline 59 & $-0.9971 \mathrm{~ns}$ & $-0.9963 \mathrm{~ns}$ & $-0.9937 \mathrm{~ns}$ & $-0.9968 \mathrm{~ns}$ \\
\hline 67 & $0.8311^{* *}$ & $0.7693^{* *}$ & $0.6001^{* *}$ & $0.8061^{* *}$ \\
\hline 68 & $0.8781^{* *}$ & $0.8255^{* *}$ & $0.7166^{* *}$ & $0.8565^{* *}$ \\
\hline 69 & $0.8884^{* *}$ & $0.8275^{* *}$ & $0.6723^{* *}$ & $0.8637^{* *}$ \\
\hline 788 & $0.9469^{* *}$ & $0.9415^{* *}$ & $0.9030^{* *}$ & $0.9450^{* *}$ \\
\hline 79 & $0.9523^{* *}$ & $0.9468^{* *}$ & $0.9072^{* *}$ & $0.9503^{* *}$ \\
\hline 89 & $0.9913^{* *}$ & $0.9869^{* *}$ & $0.9537^{* *}$ & $0.9897^{* *}$ \\
\hline
\end{tabular}

g: Genotypic, p: Phenotypic, e: Environmental, s: Simple; 1: Germination Percentage, 2: Plant Height, 3: Number of Seeds per pod, 4: Days to First flowering, 5: Days to Maturity, 6: Number of Pods per plant, 7: Hundred Grain Weight, 8: Qualitative Trait(P), 9: Qualitative Trait(F)

*Significant at $5 \%$ level of probability level ** Significant at $1 \%$ level of probability level, ns; Non significant 


\section{Conclusion}

It is concluded that that the both mutagens had different effect on soybean plant. The gamma rays at $30 \mathrm{kr}$ showed significant result on germination percentage, plant height, days to maturity and oil content. It is determined that the $0.04 \% 0 \mathrm{f}$ the chemical mutagens and $30 \mathrm{kr}$ of the gamma rays performed optimum for the yield and biochemical parameters. It also enabled us to select desirable doses of the Sodium Azide and suitable amount of gamma rays for genetic variability. Moreover, the genotype KY EXOTIC, NARC-2, AJMERI-2 performed well for all of the traits studied hence these genotypes can further be exploited for yield improvement of soybean.

\section{References}

1. Kavithamani D, Kalamani A, Vanniarajan C, Uma D (2010) Development of new vegetable soybean (Glycine max L. Merill) mutants with high protein and less fibre content. Electronic Journal of Plant Breeding 1(4): 1060-1065.

2. Government of Pakistan 2017-2018.

3. Mudibu J, Nkongolo KK, Kalonji Mbuyi A, Kizungu RV (2012) Effect of gamma irradiation on morpho-agronomic characteristics of soybeans (Glycine max L.). American Journal of Plant Sciences 3(3): 331.

4. Celik 0, Atak C, Suludere Z (2014) Response of soybean plants to gamma radiation: Biochemical analyses and expression patterns of trichome development. Plant Omics 7(5): 382.

5. Manivannan N (2014) TNAUSTAT-Statistical package. https://sites. google. com/site/tnaustat.

6. Abolude DS, Adelanwa MA, Adelanwa EB, Adamu SM (2012) Morphological Effects of Sodium Azide on Soya Bean (Glycine Max (L) MERR).

\section{ISSN: 2574-1241}

DOI: 10.26717/BJSTR.2020.25.004135

Sajid Hussain. Biomed J Sci \& Tech Res

(C) This work is licensed under Creative

Submission Link: https://biomedres.us/submit-manuscript.php
7. Khan MH, Tyagi SD (2005) Induced variation in quantitative traits due to physical (gamma rays), chemical (EMS) and combined mutagen treatments in soybean [Glycine max L.) Merrill].

8. Ahire D, Auti S (2015) Effect of chemical and physical mutagen in $\mathrm{m} 1$ generation and chlorophyll mutations in soybean (glycine max 1 . Merrill.). International Journal of Bioassays 4(8): 4235-4240.

9. Pavadai, P (2015) Studies on quantitative characters for gamma rays treatment in soybean (Glycine max (L.) Merr.) var. Co-1. International Journal of Modern Cellular and Molecular Biology 4(1): 1-10.

10. Karthika IR, Subba B (2006) Effect of gama rays and EMS on two varieties of soybean. Asian Journal of Biological Sciences 5: 721-724.

11. Malek MA, Rafii MY, Afroz SS, Nath UK, Mondal M, et al. (2014) Morphological characterization and assessment of genetic variability, character association, and divergence in soybean mutants. The Scientific World Journal.

12. Balla MY, Ibrahim SE (2017) Genotypic correlation and path coefficient analysis of soybean [Glycine max (L.) Merr.] for yield and its components. Agriculture Research Techniques 7(3): 555715.

13. Deswal RPS, N Kaushik, NS Panwar, NSL Rawat, KS Bangarwa, et al. (2015) Variability and associations in morpho-physiological traits and seed yield and oil content in Pongamia Pinnata L. Pierre. Indian Journal Agriculture. 17(1): 17-23.

14. Khan MH, Tyagi SD (2010) Induced morphological mutants in soybean [Glycine max (L.) Merrill]. Frontiers of Agriculture in China 4(2): 175180.

15. Popovic V, S Jaksic, D Glamoclija, N Grahovac, V Djekic, et al. (2012) Variability and correlations between soybean yield and quality components. Romanian Agricultural Research 29: 131-138.

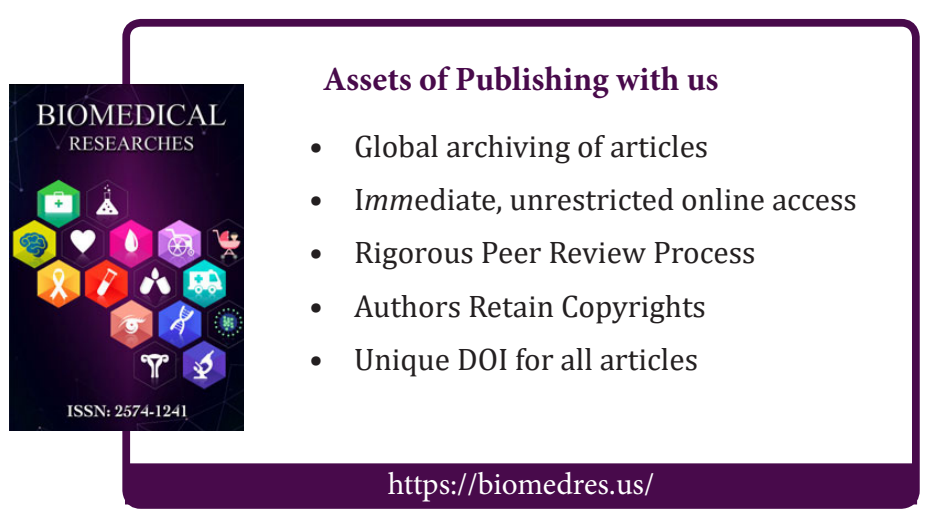

